\title{
Review and Analysis of Selected Customer Value Measurement Methods
}

\author{
Maria Kubacka*
}

The methods of measuring customer value are of constant interest. This area is widely described in the literature, but nevertheless somewhat generally. It is important to analyse the different methods comprehensively in the context of the customer and the company. The aim of this paper is to analyse the methods of measuring customer value most often presented in the literature, as well as to assess the possibility of their reliable application and to indicate the limitations resulting from the construction of models of their calculations. One very important goal is to constructively propose solutions to the problematic issues in the methods analysed. In order to achieve the objectives of the paper, methods of measuring customer value are presented. On this basis, the author has identified problematic elements that constitute guidelines for further research. A literature review and analysis of studies carried out with the use of the methods discussed is applied.

The conclusions of this research indicate ambiguity in the methods of measuring customer value, their diversity and, most importantly, the inability to reliably determine certain components of the methodology, especially for customer lifetime value. The analysis presented constitutes a proposal for a comprehensive look at the issue of customer value assessment and an element of further scientific and empirical discussion. The originality of the research consists in presenting a proposal for quantification of non-financial measures, which are a component of the methodology of measuring customer value.

Keywords: customer value measurement, CLV (customer lifetime value), RFM (reviewerfrequency-monetary value), SOW (share of wallet), PCV (past customer value).

Submitted: 04.03.2020 | Accepted: 16.06.2020

\section{Przegląd i analiza wybranych metod pomiaru wartości klienta}

Nieustajacym zainteresowaniem ciesza się metody pomiaru wartości klienta. Obszar ten wydaje się być szeroko opisywany w literaturze, niemniej jednak nieco ogólnie. Ważne jest, aby przeanalizować poszczególne metody kompleksowo w kontekście klienta i przedsiębiorstwa. Celem tego artykutu jest analiza najczęściej prezentowanych $w$ literaturze metod pomiaru wartości klienta, a także ocena możliwości rzetelnego ich zastosowania oraz wskazanie ograniczeń wynikajacych z konstrukcji modelów ich obliczeń. Niezwykle istotnym celem jest konstruktywne zaproponowanie rozwiazań kwestii problematycznych analizowanych metod. $W$ celu zrealizowania celów pracy, zaprezentowane zostaly metody pomiaru wartości klienta. $\mathrm{Na}$ tej podstawie autorka wskazała elementy problematyczne, które stanowia wytyczne dla

\footnotetext{
Maria Kubacka - MA, The Faculty of Management, Rzeszow University of Technology, Poland, https://orcid.org/0000-0002-1533-0278.

Correspondence address: Rzeszow University of Technology, Akademicka 2 St., 35-959 Rzeszów, Poland, building ARCUS, room 326; e-mail: m.kubacka@prz.edu.pl.
} 
dalszych badań. Zastosowano przegląd literatury oraz analize badań przeprowadzonych $z$ wykorzystaniem metod będacych przedmiotem pracy.

Wnioski plynące z podjętych dziatań wskazuja niejednoznaczność metod pomiaru wartości klienta, ich zróżnicowanie, a co najistotniejsze brak możliwości wiarygodnego ustalenia niektórych elementów składowych metodologii, szczególnie dla dtugookresowej wartości klienta. Zaprezentowana analiza stanowi propozycję w zakresie kompleksowego spojrzenia na problematykę wyceny wartości klienta oraz element dalszej dyskusji naukowo-empirycznej. Oryginalność pracy polega na przedstawieniu propozycji kwantyfikacji mierników niefinansowych będacych składowa metodologii pomiaru wartości klienta.

Słowa kluczowe: pomiar wartości klienta, długookresowa wartość klienta (CLV), RFM, SOW, PCV.

Nadesłany: 04.03.2020 | Zaakceptowany do druku: 16.06.2020

JEL: M21

\section{Introduction}

Peter Drucker observed that, "there is only one important definition of a business goal: to create a customer. The customer is the foundation of the business and sustains its existence" (Drucker \& Maciariello, 2004 , p. 80). The customer in the literature is considered to be one of the key sources of a company's value. This is indicated by both theoretical considerations and empirical evidence (Caputa, 2015; Dobiegała-Korona, 2011, pp. 521-522; Gupta, Lehmann, \& Stuart 2004; Kumar \& Shah, 2009; Seybold, Marshak, \& Lewis, 2001; Srivastava, Shervani, \& Fahey, 1998). P. Kotler states, "customers become the foundation on which to build a business" and, moreover, considers the customer to be king (Kotler \& Keller, 2016, p. 150).

Attaching so much importance to customers for the functioning and development of a company has increased interest in methods of measuring their value. It is noteworthy that the Marketing Science Institute has made customer value research a priority area (Sun \& Su, 2012).

It should be noted that the concept of customer value is ambiguous, interpreted differently and described by many definitions. "Customer value" in the Englishlanguage literature is understood as value for the customer (Woodruff, 1997; Lam, Shankar, Erramilli, \& Murthy, 2004; Payne \& Holt, 2001). Other authors indicate customer value as understood in terms of the long-term relationship, referred to as customer lifetime value (Doligalski, 2010). The Polish literature also has the concept of the customer's lifetime value (Cichosz, 2005).

Definitions of a customer's lifetime value reduce it to the ongoing value of the discounted cash flows resulting from the relationship with the customer (Farris, Bendle, Pfeifer, \& Reibstein, 2009; Gupta \& Lehmann, 2003; Kotler, 1974; Kumar, 2008; Pfeifer, Hakins, \& Conroy, 2005). It should be noted, however, that this wording expresses one of the perspectives for measuring customer value.

The aim of the study is to present methods of measuring customer value with particular emphasis on the analysis of their components. In an era of growing popularity of the analysed concept of customer value, an in-depth review and systematisation of the methods proposed in the literature to measure it is of great importance. Contrary to the belief that there are many publications in this area, there is a need for a synthetic characterisation and analysis of the solutions presented. In order to achieve this goal, a critical review of the literature on the subject and an analysis of the methods of measuring customer value presented have been used as research methods. The most sensitive elements influencing the determination of customer value are diagnosed and the directions of further research have been indicated.

\section{Customer Value Measurement Methods}

Estimation of customer value may be carried out retrospectively or prospectively. In the first approach, the basis for 
determining the customer value is historical data. It is assumed that in the future the customer's behaviour will be similar or the same as in the past (Caputa, 2015). On the contrary, in a prospective approach, the estimation of customer value is made on the basis of the benefits the company expects from a specific customer or group of customers in the future (Jackobs, Johnston, \& Kotchetova, 2001).

\subsection{Retrospective Methods}

The literature lists the following traditional indicators - based on historical data (Dobiegała-Korona, 2011; Dobiegała-Korona \& Doligalski 2010; Ekinci, Ülengin, Uray, \& Ülengin, 2014; Kumar, 2008):

- RFM (reviewer-frequency-monetary value),

- SOW (share of wallet),

- PCV (past customer value).

The RFM indicator is based on historical customer behaviour, in particular three key variables (Bult \& Wansbeek, 1995; Caputa, 2015; Pawłowski, Banaś, \& Pastuszak, 2016):

- customer activity, expressed in terms of time since the last purchase,

- frequency of purchases - corresponding to the number of purchases made by the customer in a given time period,

- the average value of purchases made by the customer over a certain period of time.

Each of these variables is weighted according to their importance to the company (Chuang \& Shen, 2008; Stone 1995). The RFM indicator is expressed by the formula:

$$
R F M=R \times w+M \times w+F \times w
$$

where:

$R$ - the period in days since the last purchase,

$F$ - number of purchases in period $n$,

$M$ - average value of purchases made by the customer in period $n$,

$\mathrm{w}$ - the weight assigned to each variable.

The correctness of the customer value determination using the RFM indicator depends on the correct definition of the variables, properly determined weights of the individual variables, and the accepted time interval for which the calculations are performed. This indicator is used in the mail order and catalogue industry (Gupta et al., 2006). Niknamian (2020) presents a positive use of RFM to calculate customer value in the insurance industry, too. The literature also describes the application of the RFM method to segmentation in a trading company with a sample of 1,633 customers (Pawłowski et al., 2016) and to forecasts of sales volumes (Gustriansyah, Sensuse, \& Ramadhan, 2017). Zalaghi \& Abbasnejad Varzi (2014) presented the use of an extended RFM method to identify the customer loyalty index, which was then subjected to a genetic algorithm. The process carried out in this way has shown high precision in identifying the living standards of customers.

The next indicator - SOW (share of wallet) - indicates the extent to which the customer uses the company's products/services to satisfy their needs (Kumar \& Reinartz, 2010). Keiningham, Aksoy, Buoye and Cooil (2011) conducted research on a group of 17,000 customers, analysing their purchases in a dozen or so industries in nine countries (Keiningham, Aksoy, Buoye, \& Cooil, 2011). They showed that the importance that consumers attach to the brand in relation to other brands whose products they also purchase makes it possible to predict the share of the wallet. The authors developed a new formula - the Wallet Allocation Rule - allowing the share of a specific customer's wallet to be predicted. The SOW is mainly used in the retail industry to establish customer loyalty to a particular retail outlet. It can be calculated individually or collectively. However, the basis for the preparation of appropriate marketing activities is the individual SOW indicator, the formula of which is as follows:

$$
S O W_{i}=\frac{S_{j}}{\sum_{j=1}^{J} S_{j}}
$$

where:

$S O W_{i}$ - individual SOW,

$S$ - sales to a selected customer,

$j$ - business,

$\sum_{j=1}^{J}-$ the total value of sales of the product/ service by all companies from which the customer is supplied.

In summary, the SOW represents (in percentage terms) the share of a certain 
brand or company in the customer's wallet.

The last indicator in this classification is PCV (past customer value), expressed in the formula (Kumar, 2007):

$$
P C V_{i}=\sum_{t=1}^{T} G C_{i t} \times(1+d)^{t}
$$

where:

$P C V_{i}$ - the past value of the $i$-th customer, $d$ - discount rate,

$T$ - the number of periods in which purchases were made,

$G C_{i t}$ - customer-generated margin $i$ in period $t$.

The PCV model determines the future value of the customer based on their past value. For this purpose, by extrapolating historical data, the future value of the customer, resulting from the customer's share of past profit creation, is calculated, taking into account the discount rate. The level of the PCV index provides information about the customer's past profitability. Caputa (2015, p. 54) considers it to be one of the indicators of resource allocation.

The subject literature presents the practical use of RFM, SOW and PCV indicators (Kumar \& Reinartz, 2016). It should be noted that the presented methods differ in the variables included in the equations, which constitute their integral part. Nevertheless, future-oriented customer value measurement methods are much more important. The customer, being the company's main source of income, requires special attention from it. The indicators presented allow the company's potential to be assessed by indicating the value of individual customers in the past, which unfortunately is not enough.

\subsection{Prospective Methods}

Prospective methods are widely described in the literature, and are aimed at future measurement of customer value. One of the most important of these is the CLV (Customer Lifetime Value), which has experienced a wide variety of approaches, modifications and applications, including:

- using a Monte Carlo simulation to predict customer purchasing propensity, profit and company marketing activities (Rust, Kumar, \& Venkatesan, 2011),
- using reportable data to estimate the value of the company's current customers (Pfeifer, 2011),

- using multi-channel multimedia communication (Kumar, 2010),

- allowing the use of customer value to determine the market capitalisation of a company (Kumar \& Shah, 2009),

- showing the impact on profitability and resource allocation (Kumar, Venkatesan, Bohling, \& Beckmann, 2008),

- taking into account various customer value determinants (Berger \& Nasr, 1998),

- using quantum regression (Benoit \& Van den Poel, 2009),

- using Markov models (Pfeifer \& Carraway, 2000),

- including the impact of the brand and competition on customer value (Rust, Lemon, \& Zeithaml, 2004),

- taking into account the influence of lifestyle on the customer's lifetime value (Dahana, Miwa, \& Morisada, 2019),

- taking into account the impact of the strategy on the customer's lifetime value (Hajipour \& Esfahani, 2019),

- using dynamic programming models to maximize CLV (AboElHamd, Shamma, \& Saleh, 2020).

The basic premise of the CLV is to perceive the customer value throughout the customer's entire life cycle, from the moment the relationship with the customer is established, through the phase of its growth and stabilisation, to the phase of the customer's departure.

The importance of customer relations aimed at effective customer management to increase the profitability of the company has drawn the attention of researchers to issues related to the impact of marketing expenditure on customer value (Bolton, Lemon, \& Verhoef, 2004). It also turned out to be important to actively undertake marketing activities in the aspect of contact with the customer, which lead to maximising the customer value and reducing the risk of the customer leaving (Morgan \& Hunt, 1994; Kumar, Venkatesan, \& Reinartz, 2008; Kim \& Kumar, 2018).

At present, there are over a dozen models of CLV determination; however, the construction of some of them is problematic to apply in practice. Table 1 shows selected definitions of the CLV and their corresponding equations. 
Table 1. CLV definitions

\begin{tabular}{|c|c|c|}
\hline Author & CLV definition & Equation \\
\hline $\begin{array}{l}\text { P. Kotler } \\
\text { (1974, p. 24) }\end{array}$ & $\begin{array}{l}\text { "Long-run customer profitability } \\
\text { may be viewed as the present value } \\
\text { of the future profit stream expected } \\
\text { over a given time horizon of } \\
\text { transacting with the customer." }\end{array}$ & $\begin{array}{l}\qquad Z=\sum_{t=1}^{\bar{t}} \frac{m Q_{t}-X_{t}}{(1+d)^{t}} \\
Z \text { - present value of the future } \\
\text { income from a customer, } \\
m=\text { gross margin on expected sales } \\
\text { to a customer, } \\
Q_{t} \text { - expected sales from the } \\
\text { customer in year } t \\
X_{t} \text { - cost of maintaining customer } \\
\text { contact and goodwill in year } t, \\
d-\text { company discount rate for } \\
\text { future income } \\
t-\text { a subscript for year, } \\
\bar{t} \text { - number of years that the } \\
\text { customer is expected to remain } \\
\text { a customer. }\end{array}$ \\
\hline $\begin{array}{l}\text { S. Gupta } \\
\& \text { D.R. Lehmann } \\
(2003 \text {, p. 10) }\end{array}$ & $\begin{array}{l}\text { "Customer lifetime value (CLV) } \\
\text { is the present value of all future } \\
\text { profits generated from a customer." }\end{array}$ & $\begin{array}{l}\qquad C L V=\sum_{t=1}^{n} \frac{m_{t}}{(1+d)^{t}} \\
\text { where: } m_{t}-\text { margin or contribution } \\
\text { for each customer in a given time } \\
\text { period } t \text {, } \\
d \text { - discount rate, } \\
n \text { - period over which the customer } \\
\text { is assumed to remain active. }\end{array}$ \\
\hline $\begin{array}{l}\text { Ph. Pfeifer, } \\
\text { M.E. Hakins } \\
\text { \& R.M. Conroy } \\
(2005, \text { p. 17) }\end{array}$ & $\begin{array}{l}\text { "Customer Lifetime Value (CLV) is } \\
\text { the present value of the future cash } \\
\text { flows attributed to the customer } \\
\text { relationship." }\end{array}$ & $\begin{array}{l}C L V_{i}=N C F_{1}+\frac{N C F_{2}}{1+d}+\frac{N C F_{3}}{(1+d)^{2}} \\
\quad+\frac{N C F_{4}}{(1+d)^{3}}+\cdots+\frac{N C F_{n}}{(1+d)^{n-1}} \\
N C F \text { - net cash flow, } \\
d-\text { discount rate, } \\
n \text { - period over which the customer } \\
\text { is assumed to remain active. }\end{array}$ \\
\hline $\begin{array}{l}\text { V. Kumar } \\
(2008, \text { p. 37) }\end{array}$ & $\begin{array}{l}\text { "The sum of cumulated cash flows } \\
\text { - discounted using the weighted } \\
\text { average cost of capital (WACC) } \\
\text { - of a customer over his or her } \\
\text { entire lifetime with the company". }\end{array}$ & $\begin{array}{l}\quad C L V_{i}=\sum_{t=1}^{T} \frac{\left(F M_{i t}-F C_{i t}\right)}{(1+d)^{t}} \\
F M \text { - future contribution margin, } \\
F C \text { - future cost, } \\
i \text { - customer index, } \\
t \text { - time index, } \\
d \text { - discount rate. }\end{array}$ \\
\hline $\begin{array}{l}\text { P. Farris, N. Bendle, } \\
\text { Ph. Pfeifer } \\
\text { \& D. Reibstein } \\
(2009, \text { p. } 143)\end{array}$ & $\begin{array}{l}\text { "Customer lifetime value (CLV): } \\
\text { The present value of the future cash } \\
\text { flows attributed to the customer } \\
\text { relationship". }\end{array}$ & $\begin{array}{r}C L V=\text { Margin } * \frac{\text { Retention rate }(\%)}{1+\text { Dicsount rate }(\%)} \\
- \text { Retention rate }(\%)\end{array}$ \\
\hline
\end{tabular}




\begin{tabular}{|c|c|c|}
\hline Author & CLV definition & Equation \\
\hline $\begin{array}{l}\text { P. Kotler } \\
\text { \& K.L. Keller } \\
(2016, \text { p. } 160)\end{array}$ & $\begin{array}{l}\text { "Customer lifetime value (CLV) } \\
\text { describes the net present value } \\
\text { of the stream of future profits } \\
\text { expected over the customer's } \\
\text { lifetime purchases. The company } \\
\text { must subtract from its expected } \\
\text { revenues the expected costs of } \\
\text { attracting, selling, and servicing the } \\
\text { account of that customer, applying } \\
\text { the appropriate discount rate". }\end{array}$ & $\begin{array}{l}\quad C L V_{i}=\frac{\left(R_{i}-C_{i}\right)}{(1+d)^{t}} \\
R_{i}-\text { revenues of customer } i \\
\text { in period } t \\
C_{i}-\text { costs of customer } i \text { in period } t, \\
d-\text { discount rate } \\
t-\text { time index. }\end{array}$ \\
\hline
\end{tabular}

Source: own elaboration.

It should be noted that the definition of Kotler presented in the table (1974, p. 24) refers to long-term profitable customers. In this respect, the difference between profitability and value results from the period taken into account. Profitability is established on the basis of historical data, especially in the short term. The CLV is a strategic model for long-term customer relationship forecasting (Čermák, 2015). Nevertheless, the long-term profitability of a customer has a bearing on their value. Moreover, the author, referring to profitability, perceives it in a future perspective. For this reason, the presented definition should be identified with the customer lifetime value. This is determined by the longterm, prospective view of profitability.

An analysis of the CLV definitions leads to the following conclusions:

- first of all, the quoted authors agree that the customer value is the future value of the net discounted cash flows (representing the difference between the revenues the customer generates for the business and the expenditure incurred to acquire and maintain the customer throughout the duration of the customer-business relationship). Some authors (Gupta \& Lehmann, 2003, p. 10) propose discounting the margin which corresponds to the profits generated by customers in this case,

- secondly, as regards the definition of costs, none of the authors specify them precisely, which gives rise to some doubts as to the interpretation and recognition of those costs. There is also no agreement in the literature on accounting and finance. Both the definition of customer costs and their classification are interpreted differently. Shapiro, Rangan, Moriarty and Ross (1987) distinguish between presales costs, production costs, distribution costs, after-sales service costs as part of customer costs; Ness, Schroeck, Letendre and Douglas (2001) customer acquisition costs, provisioning costs, customer service and retention costs; Blattberg, Getz and Thomas (2004) customer acquisition and retention costs and additional sales costs; Elias and Hill (2010) product, service and maintenance costs; and Blocher, Stout and Cokins (2010) unit cost: at customer level, at transaction level and cost of customer, distribution channel and sales.

These shortcomings are minimised to a degree by an extensive formula for calculating the customer's lifetime value, which was proposed by Bauer, Hammerschmidt and Braehler (2003, p. 54) in "Year of Marketing and Consumer Research":

$$
P L V_{i}=A C_{i}+\sum_{t}^{T}\left(\begin{array}{c}
r_{t i}^{t} \times \frac{\left(A R_{t i}+U R_{t i}+C R_{t i}+R V_{t i}\right)-\left(S C_{t i}+M C_{t i}\right)}{(1+d)^{t}} \\
-\left(r_{t i}^{t-1} \times\left(1-r_{t i}\right) \times \frac{T C_{i}}{(1+d)^{t}}+r_{t i}^{t} \times\left\{\frac{\operatorname{InfoV} V_{t i}+\operatorname{Coop}_{t i}+\text { InnoV }_{t i}}{(1+d)^{t}}\right.\right.
\end{array}\right)
$$

where:

$C L V_{i}-\mathrm{CLV}$ of customer $i$,

$A C_{i}$ - acquisition costs of customer $i$,

$r_{t i}$-retention rate of customer $i$ in period $t$, in period $t$, 
$U R_{t i}$ - up selling revenue of customer $i$ in period $t$,

$C R_{t i}$ - cross selling revenue of customer $i$ in period $t$,

$R V_{t i}$ - gross contributions from reference activities of customer $i$ in period $t$,

$S C_{t i}$ - costs for serving the customer $i$ in period $t$,

$M C_{t i}$ - marketing costs for retaining customer $i$ in period $t$,

$T C_{i}$ - termination costs for the relationship with customer $i$,

Info $V_{t i}$ - information value of customer $i$ in period $t$,

Coop $V_{t i}$ - cooperation value of customer $i$ in period $t$,

Inno $V_{t i}$ - innovation value of customer $i$ in period $t$.

The above formula, taking into account the customer's life cycle, calculates the costs associated with the customer and the benefits generated by the customer for the company. Definitely, this equation allows the customer value to be determined in a more reliable way compared to the solutions presented in Table 1 . This is due to the separation of individual components of the model.

\section{Advantages and Disadvantages of Customer Value Measurement Methods}

The formula for determining the customer lifetime value (Bauer et al., 2003, p. 54) is often quoted in the literature. Certainly, the popularity of the model is determined to a large extent by its broad approach to customer value. The other equations presented in this paper do not cover as comprehensively the cash flows generated from customers, as the general formulas expressing the benefits of customers in the form of customer receipts and expenses incurred in acquiring, maintaining and servicing them are not enough. At the same time, methods based solely on the past relationship between the customer and the company are far too little. Of course, it is extremely important to know the history of the relationship with each customer in order to obtain information that is the basis for extrapolating data to determine the customer value. In particular, however, it is the methods of measuring the customer value that are most desirable for future relations.
In this aspect, once again, the equation of Bauer et al. should be analysed, from which it is clear that customer value consists of financial and non-financial elements. Financial measures are much easier to determine, and do not cause any major problems. Amongst these, the company is able to determine direct customer receipts without great difficulty when issuing invoices. The situation is different when a company sells its products to mass customers without detailed registration of their data (e.g. only a fiscal receipt). Then there are two options: using customer cards (which by name belong to a specific customer and, thanks to an appropriate IT system, record all transactions in which the customer uses the card) or treating such customers as one of the segments. At the same time, determining the cost of products manufactured, goods sold, or services provided is not complicated either. It requires these categories to be verified in the company's financial and accounting system or, if the unit has a CRM class system (customer relationship management), this information should also be included.

Nevertheless, the presented formula for measuring the customer value includes non-financial parameters, which causes some quantification difficulties in determining the level of, among other things, such components as the value of cooperation or information obtained from customers. Various solutions are presented in the literature. In particular in the indirect aspect (Kumar 2018, pp. 9-12). The problem arises especially when we analyse:

- the cost of acquiring a customer,

- customer service costs,

- marketing costs of customer maintenance,

- income from customer references,

- costs of ending the relationship with the customer,

- the value of information obtained from the customer,

- the value of cooperation with the customer,

- the value of innovation, ideas obtained from the customer.

Pfeifer (2005, p. 179) conducted a study on the cost of acquiring a customer, analysing the claim that the cost of acquiring a new customer is five times higher than the cost of maintaining an existing customer. The question is whether such a high level of 
costs is not due to miscalculation. Assuming that the company calculates the costs incurred for the campaign aimed at potential customers in full only for the customers acquired, the cost of acquiring a customer will in fact depend on the number of customers acquired. Unfortunately, such an approach does not reliably reflect the unit customer acquisition costs incurred. This is because it overburdens the newly acquired customers.

Elias and Hill (2010, pp. 18-19) mention, as part of the customer service costs, marketing, distribution and sales costs, and after-sales service costs, including guarantees and repairs. The costs of maintaining a customer are the costs incurred by the company for all activities related to maintaining existing customers (Blattberg, Getz, $\&$ Thomas 2004). Such a broad coverage of customer service costs, even though they are expressed in value and are a financial category, makes it very difficult to determine them reliably per specific customer. Just as for the cost of acquiring a customer, no ideal solution has been developed for servicing them in terms of assigning value to individual customers. Unfortunately, such a state of affairs distorts the value of individual customers, which in this situation depends indirectly on the method of calculation of the analysed costs adopted.
Establishing non-financial measures determining customer value is even more complicated. Nevertheless, they undoubtedly affect this value and disregarding them will start to reduce the company's awareness of the value of its customers.

The non-financial measure is the income from references described in the literature as customer referral value (CRV). It turns out that customers trust the opinions of their friends much more $-84 \%$ - than they trust the opinions of salespeople - only 24\% (Xevelonakis, 2016, p. 13). Also interesting in this respect are surveys carried out on a sample of 16,600 customers $(9,900$ customers from a telecommunications company and 6,700 customers from a financial services company). They showed that only $8 \%$ of potential customers acquired by order of telecommunications company customers became profitable customers, and $11 \%$ of the customers from the financial services company (Kumar, Petersen, \& Leone 2007). Kumar et al. (2007, p. 4) present the formula for determining the CRV value as the sum of the values of customers who became customers of the company by recommendation, and customers who became customers of the company for other reasons divided by the discount rate:

$$
\begin{aligned}
C R V_{i} & =\frac{\text { Value of customers who joined because of referral }}{\text { Discount Rate }} \\
& +\frac{\text { Value of customers that would join anyway }}{\text { Discount Rate }}
\end{aligned}
$$

The researchers also showed a questionable correlation between CLV and CRV, in the sense that a high CLV is not a good predictor of CRV, which also affects the recognition of CRV as a questionable component of CLV. Schmitt, Skiera and Van den Bulte (2011), on the other hand, conducted research on a sample of approximately 10,000 clients of a German bank, analysing their behaviour over 33 months. The authors concluded that the recommended customers have higher margins and higher retention rates and are more valuable both in the short and long term. Compared to a customer who has not received a recommendation for the company's products, the average value of a customer by recommen- dation is at least $16 \%$ higher (Schmitt et al., 2011). Similar conclusions were drawn by Armelini, Barrot and Becker (2015). Their research has shown that there is a demographic probability between the referrer and the recipient of the recommendation increasing the value of the referred customer, in particular when the referrer has a high CLV.

A similar indicator of customer influence on other customers - potential and current - is CIV (customer influencer value). The difference between the CRV and the CIV is that the CRV is associated with compensation for each successful referral, while the CIV is entirely voluntary and generally not associated with a return 
service (Kumar et al., 2010). Moreover, the CIV covering the impact of the customer's actions through blogs and social media is characterised by a relationship with CLV in such a way that a high CLV may indicate a positive attitude of the customer towards the company, whose communication with other people may increase the CIV (Kumar et al., 2010).

The activities related to the termination of the customer relationship are broadly described by Mittal, Sarkees and Murshed (2008). Buttle and Maklan (2015, pp. 37-39) mention the loss of control, the costs of ending the relationship, the commitment of resources and the costs of lost opportunities as reasons why companies do not want to continue their relationships with customers. The terminology for ending the relationship with the customer is also diversified, as presented by Geersbro and Ritter (2010, pp. 3-4).Of course, the action to end the relationship should be properly planned so that it does not adversely affect the company (Kabue, Gathenya, \& Kihoro, 2015).

Bauer et al. (2003, p. 53) explain the other components of the proposed CLV model as follows:

- The value of information from the customer is the monetary benefit of the information obtained, less the cost of obtaining it,

- The value of innovation and cooperation is expressed through knowledge transfer or product and process innovation.

The value of cooperation, co-creating value with the customer is the subject of both theoretical and empirical discussion. The practice shows how businesses can benefit from working with customers who submit innovations, ideas, or design new solutions or products (Agrawal \& Rahman, 2015; Crandell, 2016; Darmody, 2009; Galvagno \& Dalli, 2014, Kuo, Luarn, \& Chen, 2017; Yen, Teng, \& Tzeng, 2020). Yi says, "Customers play a key role as value creators" (2014, p. 3). This is illustrated by the example of IKEA, a company that allows customers to develop their own product solutions and assess their product designs. In this way, IKEA transforms the customer into a co-creator of value (Gibbert, Leibold, \& Probst 2002, p. 464). Companies that successfully use the concept of co-creation with clients include LEGO, DHL, DE WALT, and BMW. However, there is one fundamental problem in this regard - the valuation of this cooperation. Tomczyk (2016) presented the theoretical basis for the CKV (customer knowledge value), proposing two dimensions for measuring it depending on the type of beneficiary's value and their activities and on the phase of the customer's life cycle. In addition, the author points to uncertainties regarding $\mathrm{KfC}$ (knowledge from customer), which may imply the need to create different CKV models for different KfC dimensions (Tomczyk, 2018). However, there is a lack of specific solutions that translate into measurable values for the valuation of customers' contributions to the co-creation process.

The question then arises: how to reliably determine the value of individual non-financial measures? In this perspective, it is certainly necessary to look for innovative solutions that will enable the quantification of particular areas determining customer value, will be effective, relatively easy to implement, and not too time-consuming. All this to ensure that the benefits are greater than the costs of any solutions. An interesting proposal in this context may turn out to be the use of IT systems, surveys, interviews with customers, and analysis of the company's activities within the framework of customer relations. As part of their recommendation income, companies may use vouchers, discounts for referrals, with specific identification of the referrer and the referee. A solution such as this allows those who have become the company's customers due to a specific, current customer to be successively monitored. In this way, the immeasurable value of a recommendation becomes, firstly, recorded and, secondly, financially measurable. The value of information obtained from the customer and the value of cooperation with them should be analysed in terms of the possibility of use in the process of design, production and translation into innovation of the proposed solutions. To this end, it would be necessary to establish the percentage contribution of the customer to, for example, the product development process and, subsequently, to prepare forecasts of the margin generated on their sales in the estimated life cycle of the product. The value of cooperation with the customer established in this way would constitute a measurable element of 
customer value (of course this value should be subject to the process of discounting). Certainly, the still under-exploited potential of Customer Relationship Management (CRM) systems offers great opportunities to collect non-financial customer information, which can then, for example, be ranked to try to quantify it.

The difficulty of measuring non-financial elements of customer value, both in theory and in practice, should not affect their omission. On the contrary, the identification of non-financial measures as key components of customer value forces interest in the methods of measuring them.

\section{Conclusion}

The aim of the paper was to present selected methods of measuring customer value with an indication of their problematic elements. The analysis shows that current methods of measuring customer value, although used in company practice, are not sufficient and the literature does not comprehensively cover all elements of customer value that should be subject to valuation. In addition, many of the components do not have a clearly defined calculation formula, which further complicates the reliable determination of customer value.

The value of a company's customers largely determines its success. That is why it is so important to use methods of measuring their value. Unfortunately, this is not an easy task, and companies that value their clients do not take into account the whole spectrum of factors determining their value. This is due to the fact that most of the factors influencing customer value are not strictly financial factors, are not recorded in the financial and accounting system or in the CRM system, which further makes calculations difficult. Omitting non-financial components of customer value, such as the value of information obtained from the customer, cooperation, and recommendations significantly distorts the valuation. Moreover, the method of accounting for the customer's indirect costs also raises concerns. There is also no indisputable solution in this respect. This state of affairs can result in inappropriate decisions by the company in terms of customer management, which may have disastrous results. A detailed critique of customer value is presented by Doligalski (2013, pp. 247-248).

Comprehensively identified problematic elements of customer value assessment indicate the direction for further research. The non-financial components highlighted in particular are sufficiently important to continue the scientific and empirical discussion on this issue. Different positions are presented in the literature, but in particular, practice requires clearly defined and, above all, measurable elements that create customer value. It would be interesting for those involved in finance and mathematics to take the initiative to develop an appropriate calculation algorithm. The components of the customer value model also need to be considered in terms of the elements to be included (e.g. demographic data), which is undoubtedly a challenge for further research. Customer value as an extremely important (if not the most important) piece of information for companies certainly requires interest from business researchers and practitioners.

\section{References}

AboElHamd, E., Shamma, H.M., \& Saleh, M. (2020). Maximizing customer lifetime value using dynamic programming: Theoretical and practical implications. Academy of Marketing Studies Journal, 24(1), 1-25.

Agrawal, A.K., \& Rahman, Z. (2015). Roles and resource contributions of customers in value co-creation. International Strategic Management Review, 3(1-2), 144-160. http://dx.doi.org/10.1016/j. ism.2015.03.001.

Armelini, G., Barrot, C., \& Becker, J.U. (2015). Referral programs, customer value, and the relevance of dyadic characteristics. International Journal of Research in Marketing, 32(4), 449-452. http:// dx.doi.org/10.1016/j.ijresmar.2015.09.004.

Bauer, H.H., Hammerschmidt, M., \& Braehler, M. (2003). The customer lifetime value concept and its contribution to corporate valuation. Yearbook of Marketing and Consumer Research, 1, 47-67.

Benoit, D.F., \& Van den Poel, D. (2009). Benefits of quantile regression for the analysis of customer lifetime value in a contractual setting: An application in financial services. Expert Systems with Applications, 36(7), 10475-10484. http://dx.doi. org/10.1016/j.eswa.2009.01.031.

Berger, P.D., \& Nasr, N.I. (1998). Customer lifetime value: Marketing models and applications. Journal of Interactive Market- 
ing, 12(1), 17-30. http://dx.doi.org/10.1002/ (SICI)1520-6653(199824)12:1\%3C17::AIDDIR3\%3E3.0.CO;2-K.

Blattberg, R.C., Getz, G., \& Thomas, J.S. (2004). Klient jako kapitat. Budowa cennego majątku relacji z klientem i zarzadzanie nim. Konstancin-Jeziorna: Wydawnictwo MT Biznes.

Blocher, E.J., Stout, D.E., \& Cokins, G. (2010). Cost management. A strategic emphasis (5th ed.). New York: McGraw-Hill Irwin.

Bolton, R.N., Lemon, K.N., \& Verhoef, P.C. (2004). The theoretical underpinnings of customer asset management: A framework and propositions for future research. Journal of the Academy of Marketing Science, 32(3), 271-292. http://dx.doi. org/10.1177/0092070304263341.

Bult, J.R., \& Wansbeek, T. (1995). Optimal selection for direct mail. Marketing Science, 14(4), 378-394. http://dx.doi.org/10.1287/mksc.14.4.378.

Buttle, F. \& Maklan, S. (2015). Customer relationship management: Concepts and technologies (3rd ed.). Abingdon, Oxon; New York, NY: Routledge, Taylor and Francis Group.

Candell, Ch. (2016). Customer co-creation is the secret sauce to success. Forbes, 16.10.2016. Retrieved on 25 June 2020 from https://www.forbes. com/sites/christinecrandell/2016/06/10/customer_ cocreation_secret_sauce/\#6de498565b6d.

Čermák, P. (2015). Customer profitability analysis and customer life time value models: Portfolio analysis. Procedia Economics and Finance, 25, 14-25. http://dx.doi.org/10.1016/S2212-5671(15)00708-X.

Chuang, H., \& Shen, C. (2008). A study on the applications of data mining techniques to enhance customer lifetime value - Based on the department store industry. 2008 International Conference on Machine Learning and Cybernetics, 1, 168-173.

Cichosz, M. (2005). Życiowa wartość klienta i jej znaczenie dla firmy. Marketing i Rynek, 12, 9-14.

Dahana, W.D., Miwa, Y., \& Morisada, M. (2019). Linking lifestyle to customer lifetime value: An exploratory study in an online fashion retail market. Journal of Business Research, 99, 319-331. https:// doi.org/10.1016/j.jbusres.2019.02.049.

Darmody, A. (2009). Value co-creation and new marketing. Open Source Business Resource. Retrieved from http://timreview.ca/article/302.

Dobiegała-Korona, B. (2011). Wycena klienta. In M. Panfil \& A. Szablewski (Eds.), Wycena przedsiębiorstwa. Od teorii do praktyki (pp. 521-549). Warszawa: Poltex.

Doligalski, T. (2010). Wartość a rentowność klienta. In B. Dobiegała-Korona \& T. Doligalski (Eds.), Zarzadzanie wartościa klienta. Pomiar $i$ strategie (pp. 73-85). Warszawa: POLTEXT.
Doligaski, T. (2013). Internet $w$ zarządzaniu wartościa klienta. Warszawa: Oficyna Wydawnicza Szkoła Główna Handlowa w Warszawie.

Drucker, P.F., \& Maciariello, J.A. (2004). The daily Drucker: 366 days of insight and motivation for getting the right things done. New York: HarperBusiness.

Ekinci, Y., Ülengin, F., Uray, N., \& Ülengin, B. (2014). Analysis of customer lifetime value and marketing expenditure decisions through a Markovian-based model. European Journal of Operational Research, 237(1), 278-288. http://dx.doi. org/10.1016/j.ejor.2014.01.014.

Elias, N., \& Hill, D. (2010). Customer profitability management. Business performance management. Statements on management accounting, 67. New Jersey: Institute of Management Accountants.

Farris, P.W., Bendle, N.T., Pfeifer, P.E., \& Reibstein D.J. (2009). Key marketing metrics. The 50+ metrics every manager needs to know. UK: FT Prentice Hall.

Galvagno, M., \& Dalli, D. (2014). Theory of value co-creation: A systematic literature review. Managing Service Quality: An International Journal, 24(6), 643-683. http://dx.doi.org/10.1108/MSQ-09-20130187.

Geersbro, J., \& Ritter, T. (2010). Antecedents of customer relationship termination. Paper presented at Industrial Marketing and Purchasing Conference: IMP 2010, Budapest, Hungary. Retrieved on 25 June 2020 from http://www.impgroup.org/ paper_view.php?viewPaper $=7455$.

Gibbert, M., Leibold, M., \& Probst, G. (2002). Five styles of customer knowledge management, and how smart companies use them to create value. European Management Journal, 20(5), 459-469. http://dx.doi.org/10.1016/S0263-2373(02)00101-9.

Gupta, S., Hanssens, D., Hardie, B., Kahn, W., Kumar, V., Lin, N., Ravishanker, N., \& Sriram, S. (2006). Modeling customer lifetime value. Journal of Service Research, 9(2), 139-155. http://dx.doi. org/10.1177/1094670506293810.

Gupta, S., \& Lehmann, D.R. (2003). Customers as assets. Journal of Interactive Marketing, 17(1), 9-24. http://dx.doi.org/10.1002/dir.10045.

Gupta, S., Lehmann, D.R., \& Stuart, J.A. (2004). Valuing customers. Journal of Marketing Research, 41(1), 7-18. http://dx.doi.org/10.1509/ jmkr.41.1.7.25084.

Gustriansyah, R., Sensuse, D.I. \& Ramadhan, A. (2017). A sales prediction model adopted the recency-frequency-monetary concept. Indonesian Journal of Electrical Engineering and Computer Science, 6, 711-720. http://dx.doi.org/10.11591/ijeecs. v6.i3.pp711-720. 
Hajipour, B. \& Esfahani, M. (2019). Delta model application for developing customer lifetime value. Marketing Intelligence \& Planning, 37(3), 298-309. https://doi.org/10.1108/MIP-06-2018-0190.

https://ikeacocreation.com/

Jacobs, F.A., Johnston, W., \& Kotchetova, N. (2001). Customer profitability. Prospective vs. retrospective approaches in a business-to-business setting. Industrial Marketing Management, 30(4), 353-363.

Kabue, H.W., Gathenya, J.W., \& Kihoro, J.M. (2015) Customer relationship termination and marketing effectiveness in commercial banks. International Journal of Business and Social Science, 6(10), 28-35.

Keiningham, T.L., Aksoy, L., Buoye, A., \& Cooil, B. (2011). Customer loyalty isn’t enough. Grow your share of wallet. Harvard Business Review 89(10), 29-31.

Kim, K.H., \& Kumar, V. (2018). The relative influence of economic and relational direct marketing communications on buying behavior in businessto-business markets. Journal of Marketing Research, 55(1), 48-68. http://dx.doi.org/10.1509/jmr.16.0283.

Kotler, Ph. (1974). Marketing during periods of shortage. Journal of Marketing, 38(3), 20-29. http:// dx.doi.org/10.1177/002224297403800305.

Kotler, Ph. (2003). Marketing insights from $A$ to $Z$. 80 concepts every manager needs to know. Hoboken, New Jersey: John Wiley \& Sons.

Kotler, Ph., \& Keller, K.L. (2016). Marketing management (15th global ed.). Pearson.

Kumar, V. (2007). Customer lifetime value - The path to profitability. Foundations and Trends ${ }^{\circledR}$ in Marketing, 2(1), 1-96. http://dx.doi. org/10.1561/1700000004.

Kumar, V. (2008). Managing customers for profit: Strategies to increase profits and build loyalty. Upper Saddle River, New Jersey: Prentice Hall, Pearson.

Kumar, V. (2010). A customer lifetime value-based approach to marketing in the multichannel, multimedia retailing environment. Journal of Interactive Marketing, 24(2), 71-85. http://dx.doi.org/10.1016/j. intmar.2010.02.008.

Kumar, V. (2018). A theory of customer valuation: Concepts, metrics, strategy and implementation. Journal of Marketing, 82(1), 1-19. http://dx.doi. org/10.1509/jm.17.0208.

Kumar, V., \& Reinartz, W. (2010) Customer relationship management: Concept, strategy, and tools. Second Edition, Berlin Heidelberg: Springer-Verlag.

Kumar, V., \& Reinartz, W. (2016). Creating enduring customer value. Journal of Marketing, 80(6), 36-68. http://dx.doi.org/10.1509/jm.15.0414.
Kumar, V., Aksoy, L., Donkers, B., Venkatesan, R., Wiesel, T., \& Tillmanns, S. (2010). Undervalued or overvalued customers: Capturing total customer engagement value. Journal of Service Research, 13(3), 297-310. http://dx.doi. org/10.1177/1094670510375602.

Kumar, V., Petersen, J.A., \& Leone, R.P. (2007). How valuable is word of mouth?. Harvard Business Review 85(10), 1-8.

Kumar, V., \& Shah, D. (2009). Expanding the role of marketing: From customer equity to market capitalization. Journal of Marketing, 73(6), 119-136. http://dx.doi.org/10.1509/jmkg.73.6.119.

Kumar, V., Venkatesan, R. \& Reinartz, W. (2008). Performance implications of adopting a customerfocused sales campaign. Journal of Marketing, 72(5), 50-68. http://dx.doi.org/10.1509/jmkg.72.5.050.

Kumar, V., Venkatesan, R., Bohling, T., \& Beckmann, D. (2008). The power of CLV: Managing customer lifetime value at IBM. Marketing Science, 27(4), 585-599. Retrieved on 24 June 2020 from www.jstor.org/stable/40057110.

Kuo, H., Luarn, P. \& Chen, I.J. (2017). Value cocreation of Xiaomi in China. International Journal of Business and Economic Sciences Applied Research (IJBESAR), 11(1). Retrieved from https://ssrn.com/ abstract $=3155117$.

Lam, S.Y., Shankar, V., Erramilli, M.K., \& Murthy, B. (2004). Customer value, satisfaction, loyalty, and switching costs: An illustration from a business-to-business service context. Journal of the Academy of Marketing Science, 32(3), 293-311. http://dx.doi.org/10.1177/0092070304263330.

Mittal, V., Sarkees, M. \& Murshed, F. (2008). The right way to manage unprofitable customer. Harvard Business Review, 86(4), 94-102.

Morgan, R.M. \& Hunt, S.D. (1994). The commitment-trust theory of relationship marketing. Journal of Marketing, 58(3), 20-38. http://dx.doi. org/10.2307/1252308.

Ness, J.A., Schroeck, M.J., Letendre, R.A., \& Douglas, W.J. (2001). The role of ABM in measuring customer value. Part two. Strategic Finance, 82(10), 44-47.

Niknamian, S. (2020). The use of customer value changing trends in business analysis. Quantitative Economics and Management Studies, 1(2). https:// doi.org/10.35877/454RI.qems1299.

Pawłowski, M., Banaś, J., \& Pastuszak, Z. (2016). Wykorzystanie metody RFM do segmentacji klientów w celach marketingowych. Badanie na podstawie danych z firmy handlowej. Annales Universitatis Maria Curie-Skłodowska, sectio $H$ - Oeconomia, 50(2), 49-67. https://doi. org/10.17951/h.2016.50.2.49. 
Payne, A., \& Holt, S. (2001). Diagnosing customer value: Integrating the value process and relationship marketing. British Journal of Management, 12(2), 159-182. http://dx.doi.org/10.1111/14678551.00192 .

Pfeifer, P.E. (2005). The optimal ratio of acquisition and retention costs. Journal of Targeting, Measurement and Analysis for Marketing, 13(2), 179-188. http://dx.doi.org/10.1057/palgrave.jt.5740142.

Pfeifer, P.E. (2011). On estimating current-customer equity using company summary data. Journal of Interactive Marketing, 25(1), 1-14. http://dx.doi. org/10.1016/j.intmar.2010.06.001.

Pfeifer, P.E., \& Carraway, R.L. (2000). Modeling customer relationships as Markov chains. Journal of Interactive Marketing, 14(2), 43-55. http://dx.doi.org/10.1002/ (SICI)1520-6653(200021)14:2\%3C43::AIDDIR4\%3E3.0.CO;2-H.

Pfeifer, Ph., Hakins, M.E., \& Conroy, R.M. (2005). Customer lifetime value, customer profitability, and the treatment of acquisition spending. Journal of Managerial Issue, 17(1), 11-25.

Rust, R.T., Kumar, V., \& Venkatesan, R. (2011). Will the frog change into a prince? Predicting future customer profitability. International Journal of Research in Marketing, 28(4), 281-294. http:// dx.doi.org/10.1016/j.ijresmar.2011.05.003.

Rust, R.T., Lemon, K.N., \& Zeithaml, V.A. (2004). Return on marketing: Using customer equity to focus marketing strategy. Journal of Marketing, 68(1), 109-127. http://dx.doi.org/10.1509/ jmkg.68.1.109.24030.

Schmitt, P., Skiera, B., \& Van den Bulte, C. (2011). Referral programs and customer value. Journal of Marketing, 75(1), 46-59. http://dx.doi.org/10.1509/ jm.75.1.46.

Seybold, P., Marshak, R.T., \& Lewis, J.M. (2001). The customer revolution. Random House Business Books.

Shapiro, B.P., Rangan, V.K., Moriarty, R.T., \& Ross, E.B. (1987). Manage customers for profits (not just sales). Harvard Business Review, 65(5), 101-108.

Srivastava, R.K., Shervani, T.A., \& Fahey, L. (1998). Market-based assets and shareholder value: A framework for analysis. Journal of Marketing, 62(1), 2-18. http://dx.doi.org/10.2307/1251799.

Sun, H., \& Su, Z. (2012). New thoughts of customer value study. Physics Procedia, 24, 1232-1237. http:// dx.doi.org/10.1016/j.phpro.2012.02.184.

Stone, B. (1995). Successful direct marketing methods. Lincolnwood: NTC Business Books.

Tomczyk, P. (2018). Knowledge from customers. Definition and research areas. Handel Wewnętrzny, 4(375), 377-389.

Tomczyk, P. (2016). Customer knowledge valuation model based on customer lifecycle. Marketing $i$ Zarzadzanie, 5(46), 87-94. http://dx.doi. org/10.18276/miz.2016.46-09.

Xevelonakis, E. (2016). Social influence and customer referral value. Athens Journal of Business and Economics, 2(1), 7-16. http://dx.doi.org/10.30958/ ajbe.2-1-1.

Yen, C.-H., Teng, H.-Y., \& Tzeng, J.-C. (2020). Innovativeness and customer value co-creation behaviors: Mediating role of customer engagement. International Journal of Hospitality Management, 88 (article 102514) 1-11. http://dx.doi.org/10.1016/j. ijhm.2020.102514.

Yi, Y. (2014). Customer value creation behavior. London: Routledge, https://doi. org/10.4324/9781315771847.

Woodruff, R.B. (1997). Customer value: The next source for competitive advantage. Journal of the Academy of Marketing Science, 25(2), 139-153. http://dx.doi.org/10.1007/BF02894350.

Zalaghi, Z., \& Abbasnejad Varzi, Y. (2014). Measuring customer loyalty using an extended RFM and clustering technique. Management Science Letters, 4(5), 905-912. http://dx.doi.org/10.5267/j. msl.2014.3.026. 